\title{
Review Article \\ Energy Cane: Its Concept, Development, Characteristics, and Prospects
}

\author{
Sizuo Matsuoka, ${ }^{1}$ Anthony J. Kennedy, ${ }^{2}$ Eder Gustavo D. dos Santos, \\ André L. Tomazela, ${ }^{1}$ and Luis Claudio S. Rubio ${ }^{1}$ \\ ${ }^{1}$ Vignis Ltda. Fazenda São Pedro, CP 62, 62.13830-000 Santo Antonio de Posse, SP, Brazil \\ ${ }^{2}$ West Indies Central Sugar Cane Breeding Station, Groves, St. George, Barbados \\ Correspondence should be addressed to Sizuo Matsuoka; sizuo.matsuoka@gmail.com
}

Received 9 May 2014; Accepted 7 August 2014; Published 30 September 2014

Academic Editor: Philippe Jeandet

Copyright (C) 2014 Sizuo Matsuoka et al. This is an open access article distributed under the Creative Commons Attribution License, which permits unrestricted use, distribution, and reproduction in any medium, provided the original work is properly cited.

Unlike conventional sugar cane (Saccharum spp.) energy cane is a cane selected to have more fiber than sucrose in its composition. This is obtained simply by altering the genetic contribution of the ancestral species of sugarcane using traditional breeding methods. The resulting key feature is a significant increase in biomass yield. This happens because accumulating sugar is not physiologically a simple process and results in penalty in the side of fiber and yield. This review paper describes the initial conception of fuel cane in Puerto Rico in the second half of 1970s, the present resurgence of interest in it, how to breed energy cane, and the main characteristics that make it one of the most favorable dedicated bioenergy crops. The present status of breeding for energy cane in the world is also reviewed. Its potential contribution to the renewable energy market is discussed briefly.

\section{Introduction}

Sugarcane (Saccharum spp.) is a well-known feedstock rich in sucrose which has been exploited globally in sugar production for centuries. But in the mid-1970s, the petroleum embargo by OPEC highlighted the fragility of an economy depending on a foreign energy feedstock. This caused a general attention to planning for alternative energy sources (e.g., [1]). Brazil took the lead during this period by starting a project of mass production of ethanol to use it as fuel to run cars by fermenting the sucrose of sugarcane (e.g., [2-6]), soon followed by the USA that decided to make ethanol from corn instead (e.g., [7]).

Initially, economic and strategic security reasons were the driving force of Brazil's ethanol production from sugarcane program, but later, when the debate on the planet's environment sustainability was opened, it was realized that it was the most successful program of renewable energy from biomass so far carried out (e.g., [8, 9]).

The high biomass productivity of sugarcane is the biological factor that contributes to the high positive life cycle energy balance (LCEB) of ethanol produced from it with a resultant positive balance of greenhouse gases emission (GHGE) [10, 11].

The growing interest in bioenergy in recent decades pushed scientists to better understand the plant's physiological source-to-sink process as an obvious basic step to get efficiency either in the process of capture of sun's energy by the plant or its subsequent accumulation of sugar and ultimately the use of the resultant total plant by mankind (e.g., $[12]$; see revision in $[13,14])$. As a $\mathrm{C}_{4}$ plant, sugarcane is very efficient in the photosynthetic process, so that its dry matter accumulation is one of the highest among the known plants (e.g., [15-19]).

Dry matter of Saccharum spp. is composed of sugars, mostly sucrose, and fiber, cellulose, hemicelluloses, and lignin. The species Saccharum officinarum is noted for its capacity to divert an exceptionally high proportion of photoassimilates to sucrose and store it in the culms ([20], cited in [21]). However, a favorable partition between sugar and fiber for facilitating mill extraction, high sucrose and low fiber (e.g., [21-23]), has been one of the significant constraints in the sugarcane breeding: backcrossing to S. officinarum, the sugary and low fiber ancestral species, reduces overall vigor 
and so, the varieties are more susceptible to stresses and diseases and, consequently, the productivity is restricted. The potential field productivity of sugarcane is known to be nearly 400 tons of fresh biomass per hectare per year in optimum conditions, but the world commercial average productivity is less than $25 \%$ of that value (e.g., $[13,14,16,24-26])$.

Due to that low productivity, that paradigmatic characteristic of sugarcane that is easily millable to generate only sugar was challenged by Alexander in Puerto Rico in the 1980s: for almost a decade he persevered in a crusade to convince people that exploiting the fiber side of the plant, instead of the sugar, would result in a much more profitable industry [24, 27]. But, his "energy cane management system" was rejected as will be discussed later.

Nowadays, with the growing need for alternative sources of energy other than the currently predominant petroleum matrix, there has been resurgence in interest in biomass as a renewable energy source (e.g., [28-30]). Biomass comprises several forms of biological material but those produced by dedicated crops that are grown exclusively as feedstock for energy production are discussed here.

Sugarcane stands as one of the most dependable biomass crop due to its high productivity. However, the positive and significant contribution of sugarcane to the energy matrix can be further augmented with "energy cane," a distinct form of that plant selected for total biomass production rather than for sucrose and some surplus fiber. Alexander's proposition was ahead of its time in the 1980s but now it is a relevant issue and should not be overlooked anymore. This review aims to draw attention to energy cane, presenting the history of its conception, how it is obtained, and some important characteristics that make it prospectively one of the most important renewable bioenergy feedstocks for the near future.

\section{Concept of Energy Cane}

In the 1970s Puerto Rico sugar mills were suffering severe financial crisis due to several economic-structural-political factors, resulting in both very low sugarcane productivity in the field and low recovery of sucrose in the industry [24]. This situation was aggravated by the rapid rise in prices of petroleum products. Adding to this scenario there was also an intense debate on the competition between food and energy. Alexander, with a long experience in sugarcane research, especially in physiology, together with his group of researchers, made a proposition "out of the box" as a possible measure to mitigate the intricate problem. He realized that accumulating sugar, a normal metric to evaluate sugarcane quality, was not what the plant necessarily do best: “....above all else, sugarcane is an instrument of growth, a producer of biomass unequalled by any other plant when managed as a growth commodity" as he remarked in the preface of his book [24]. With this in mind, the group succeeded in getting federal funds for a five-year multidisciplinary program to manage sugarcane as a high biomass crop, a procedure from which was coined the phrase "energy cane management" [27]. Having appropriate cultivars for higher biomass production (they observed that some clones imported from USDA's mainland breeding program and coming from their introgression project had a high biomass productive capacity; one of them was US 69-22-2, a $\mathrm{BC}_{1}$ S. spontaneum clone [24]), they established a pioneer commercial evaluation project [31]. Actually, the idea was to execute an integrated exploration of sugarcane as a biomass feedstock for multiple products instead of only the traditional sugar [24, 27, 31]. However, notwithstanding the convincing results generated by the project and many persuasive papers and presentations by the group in workshops, seminars, congresses, and so forth, from 1976 to 1984, especially by Alexander (based on Alexander's book of 1985 and on other papers cited in the text the number of oral presentations aiming to convince people of the idea of "energy cane management system" by Alexander himself and other collaborators amounted at least 40 in a time span of less than 10 years, from 1976 on), they did not succeed in affecting a change in the well-established status quo [32]. Actually, in January 1985, prefacing his above mentioned book, Alexander already expressed doubts as to whether any mill would remain operating (in Puerto Rico) when the book "goes to press" [24]. Although it happened more slowly than he predicted the sugarcane industry in Puerto Rico had continued downhill and the last remaining mill closed in 2000 [33]. With the "energy cane concept" Alexander [24] tried to convert people to a management system reoriented to a new goal of maximum total biomass production and the appropriate industrial utilization of sugarcane instead of the traditional management system exclusively for sugar (apud Alexander, page 41-42; [34]; see also [31, 35]) (Pincas Jawetz and George Samuels, acting as consultants, also tried to convince people in Brazil of the energy cane concept at that time (1985), but with no progress at all (Samuels and Jawetz), and Matsuoka and Arizono [36] showed clones usually discarded by breeding programs due to low sugar content do produce more biomass and energy under the energy cane concept). He admitted that the term "energy cane" was frequently perceived in a botanical distinguishing sense, that is, to denote a new type of plant. However, even though the plants had a somewhat distinct conformation and composition they would still be processed by conventional mills to recover sugar but with the added component of energy as a coproduct. He stressed that "energy cane" was a definition of a distinct management system and not a designation of a specific type of plant.

In the following decade, biomass acquired visible importance as a renewable source of energy (energy here in a general sense) and sugarcane breeders realized that breeding canes for fiber and not for sugar, as Alexander had stated [24, $27,34]$, could be exploited to support this growing interest (e.g., $[37,38])$. Then, the term "energy cane" was adopted as a designation for this new kind of plant (actually, even Alexander made the change to using the term "energy cane" to denote the plan itself; see the apud book from page 344 on. However, even today Alexander's initial concept is used, that is, the utilization of the conventional sugarcane for biomass; see, for instance, Leal [39], Rein [40], and Botha [41]) aimed at producing fiber or total biomass (e.g., $[19,42-44]$ ) that could be used as feedstock for any kind of industry rather than only sugar mills, and from which could be obtained a myriad of 
value-added products as suggested by Alexander [24, 27, 34]. In their proposal to remodel the weak Puerto Rican sugarcane industry by adopting the energy cane concept, Alexander's group always stressed the possibility of using the whole plant, both the juice and the fiber and also the top and the leaves, of more productive cultivars, including the production of ethanol [24].

Notwithstanding their local defeat at that time, the concept has now achieved a global acceptance.

\section{Genetic Base and Breeding for Energy Cane}

Modern sugarcane cultivars are complex poly-, alloaneuploids comprising the genome of $S$. officinarum, varying proportions of S. spontaneum chromosomes (10-23\%), and 8 to $13 \%$ of recombinant or translocated chromosomes ([45]; see revision in [46]).

These proportions probably depend on the selection pressures for adaptation to specific environments (e.g., [47]). That genetic structure is attained after several backcrosses from the original $F_{1}$ individuals derived from crosses between the ancestral S. officinarum and S. spontaneum.

Actually, they are now produced by crossing previously bred commercial or near-commercial clones and various levels of backcross and selecting advantageous genetic combinations in the resultant progeny. The varietal selections combined the levels of sugar and fiber required by the millers to get a good industrial yield of sucrose but not compromising the plants' performance in the field [48].

The species $S$. officinarum is a juicy sugary form not known in the wild state, found growing in the gardens of aborigines in the Papua-New Guinea region, that is, in strictly tropical conditions (high humidity and constant high temperatures), and later utilized by the sugar industry as commercial forms (e.g., $[46,49,50])$, whereas $S$. spontaneum is a grassy wild species encountered growing naturally in diverse environments from Africa to Southeast Asia and Pacific islands (e.g., [51-54]). Its evolution in such contrasting environments has generated a widely diverse gene pool adapted to a vast range of environments, including resistance to many diseases that attack sugarcane. These characteristics were incorporated by introgression into the $S$. officinarum genome in the pioneering breeding in Java (today Indonesia) in the late 19th century and later followed by the Indians and other breeding centers (e.g., $[46,50,55,56])$. Concerning energy cane, if one looks for higher biomass production a penalty must be paid in terms of sugar content, at least if considering the traditional sugarcane ideotype. The interest is productivity of total biomass, ultimately fiber. Although there are studies sustaining a negative relationship between sugar content and fiber content $[22,23]$, Barbados' results show that this is only true in populations that have been subjected to selection for sugar producing feedstock, that is, a relatively low fiber content and a sugar content as high as possible. In unselected populations of F1 seedlings the correlation between fiber and Brix in juice was between 0.142 and 0.160 whereas in the highly selected clones at Stage 4 this correlation was invariably negative and in the range of 0.3 to 0.5 (Kennedy, personal communication). High fiber is an important component of energy cane. It is a major component of hybrids having $S$. spontaneum as genitor as also is high vigor and high biomass production; conversely, the low sugar content, also a product of the S. spontaneum genome, is not a disadvantage from the energy point of view [24].

Hybrids produced by crossing the wild species S. spontaneum with either $S$. officinarum or existing commercial varieties or near-commercial clones lead to a very wide segregation of characteristics in the $F_{1}$ population and many transgressive forms showing that high heterosis may be identified $[57,58]$. Depending on particular commercial interest, distinct individuals could be selected from these populations that tended towards the traditional sugarcanes or to the ideotype of the energy canes as defined here. Genetically, the distinct outcome of selection is probably a direct reflection of the ratio between the S. officinarum and the S. spontaneum chromosomes: the more the contribution of this second species, the more the shifting for fiber and simultaneously for hardiness and all complementary characteristics. If energy cane is the goal, the selection pressure is for final biomass productivity and several studies have shown the potential to significantly increase it selecting clones directly from $\mathrm{F}_{1}$ population (e.g., $[19,37,57-61])$.

Roach [57] studied some crosses between S. officinarum and S. spontaneum and found heterosis for early growth, stalk length, yield, \% flowering, pollen production and \% reducing sugars, and above midparent value for stooling ability. Wang et al. [58] in crossing both S. officinarum clones and commercial sugarcane clones with $S$. spontaneum found (1) a considerable higher cane and biomass yield in the top 5\% of clones in the progeny as compared to commercial cultivar checks; (2) stalk numbers were on average of the progeny clones threefold higher and the stalk weight threefold less, relative to check cultivars. Ramdoyal and Badaloo [62] confirmed that $\mathrm{F}_{1}$ families, as compared to $\mathrm{BC}_{1}$ and $\mathrm{BC}_{2}$, have higher number of stalks and stalk height (vigor) and also higher fiber and dry matter content and, conversely, lower stalk diameter, purity, Brix, and pol. That trend is clearly an effect of the $S$. spontaneum genome, and others studies also confirmed it $([59,62,63])$.

Selected energy cane clones of Vignis' breeding program also show those characteristics, along with more rapid growth (unpublished data), confirming observations by Alexander [24] and Terajima et al. [64]. What is obvious is that $S$. spontaneum transmits the ability to produce high number of tillers $[57,58,65]$, which is very important for biomass yield [66]. This is manifested not only in plant cane but also in ratoons [24, 67]. But, in conventional sugarcane cultivars a high number of tillers (thin stalks) probably indicate a high proportion of $S$. spontaneum alleles with consequent impairment in sugar content and an increase in fiber content, a condition traditionally considered undesirable for milling purpose (e.g., $[68,69])$. Conversely, in energy cane what is required is more fiber than sugar, a combination that is also associated with high biomass productivity as has been discussed above. Also, higher S. spontaneum contribution may lead to a rhizomatous habit [57, 70], a trait that helps in increasing the resistance of the crown to stresses, mainly the 
deleterious effect of heavy traffic during harvest and hauling. In conventional sugarcane the yield declines from plant-cane to older ratoons (see review in $[67,71]$ ), but some studies have shown that in energy cane it increases from plant cane to first and second ratoons, and high productivity is maintained for at least eight ratoons $[24,61,72]$. Higher tillering ability has also been observed even in $\mathrm{BC}_{1}$ clones by several authors as will be mentioned later. Legendre and Burner [37] observed it in $\mathrm{BC}_{1}$ clones but not in $\mathrm{BC}_{2}$ and $\mathrm{BC}_{3}$.

Taking into account the observed variation, Tew and Cobil [25] classified energy canes into two categories: Type I and Type II. Type I is described as a cane closer to the conventional sugarcane but having lower sucrose content and, thus, lower purity and, conversely, a higher fiber content; Type II is a cane with only marginal content of sugar but with fiber content higher than Type I, to be used exclusively for biomass production.

Alexander's original proposal concerned only Type I canes and both the lower sugar content and the lower purity, combined with the high fiber content, were significant contributors to the failure to accept his ideas because it was expected that the Type I canes would still be processed by traditional sugar mills (high concentration of sucrose is obviously expected by the conventional sugarcane industry. High purity, that is, a high proportion of sucrose over reducing sugars (glucose and fructose) favors an efficient recovery of crystallized sugar, and below certain purity levels there is no crystallization at all. Alexander recognized the restraint of energy cane juice and advocated a series of useful options. Concerning the fiber, traditionally high fiber content is alleged by the millers to lower the efficiency of juice extraction. But Alexander considered that $85 \%$ of sugar recovery is acceptable for energy cane and that, contrary to the conservative assumption, "there is a general agreement among mill authorities $(\cdots)$ that this recovery can be accomplished, regardless of the added fiber" entering "the tandem mill train" [27]. Still those arguments play a role in the rejection of the so-called energy cane even though an expected trend is to improve the efficiency in sugar recovery with improvements in the extraction process. In industries that make ethanol together with sugar there are many advantages in adopting it, mainly when field productivity is low. One of the objectives of this review is to emphasize this option). However, rather than considering energy cane as two distinct types it would be more proper to treat it as a continuum with high sugar-low fiber at one extreme and high fiber-low sugar at the other one, an even more ample classification than did Santchurn et al. [73]. Energy cane can in fact be selected for multipurpose use, from the more elementary burning to get heat, steam, and electricity to various forms of liquid combustibles (1G or $2 / 3 G$ ), coal, gas, or even more value-added chemicals (e.g., [74-76]) in proposed biorefineries of the future (e.g., $[40,77,78])$. When conventional sugarcane variety is crossed with $S$. spontaneum the progeny shows a wide range of sugar to fiber ratios which could be useful for physiological studies concerning partitioning of all carbohydrates [79]. This partitioning also has a practical aspect as any particular feedstock use will require a specific composition and specific quality concerning each compound, or the residues left like ash, $\mathrm{K}$, and silica could result in undesirable effects in the process [80]. Knoll et al. [81] found slightly more lignin in Types I and II of energy cane compared with conventional sugarcane. They also found that delaying the harvest into late winter significantly decreased the $\mathrm{K}$ mass fraction. This could be an indication that, like in Miscanthus [82], approaching the winter (temperate climate), and consequently starting the senescence, the plant remobilizes the nutrients to the underground organs in order to help the regrowth when spring comes.

As it has been thoroughly discussed elsewhere, the Saccharum genera belong to a complex botanical group consisting of many genera: Erianthus sect., Ripidium, Miscanthus, Narenga, and Sclerostachya (e.g., [56, 83]). Genetic base broadening of the sugarcane population using all of these related genera has been suggested since the 1960s, and many programs have been doing introgression with them (e.g., [19, 46, 84-88]).

However, a very small fraction of all the available germplasms has so far been utilized and almost invariably with the aim of adding vigor characteristics to sugar producing varieties. This inevitably involved backcrossing to $S$. officinarum for two or three generations after the $\mathrm{F}_{1}$ was made (e.g., $[50,52,84,86,89,90])$. Changing the selection pressures towards varieties that produce high biomass with no emphasis on sugar is a new field for exploitation of the wild germplasm [24], and there is much scope for progress [91].

The sugarcane breeding program of the University of Puerto Rico through Dr. T.L. Chu started a pioneering program selecting high biomass cultivars in 1978 ([24, 92] and, almost simultaneously, breeding programs in continental USA also took up the same idea, rescuing clones they have got from introgression program initiated before the 1970s [93]. The joint Louisiana State University (LSU) and the HoumaUSDA program succeeded in producing some energy cane cultivars, and one, US79-1002, presented percentage of fiber as high as $28 \%$ and exceptionally high productivity: five harvests from a single planting averaged $211 \mathrm{t} \cdot \mathrm{ha}^{-1}$ per harvest, with continual yield increase from plant cane to fourth ratoon (total biomass, wet basis) against $58 \mathrm{t} \cdot \mathrm{ha}^{-1}$ for a conventional sugarcane cultivar [61]. Later Bischoff et al. [72] confirmed the high potential productivity of that variety; it gave a steady linear increase in productivity, departing from $182 \mathrm{t} \cdot \mathrm{ha}^{-1}$ in plant cane to reach $247 \mathrm{t} \cdot \mathrm{ha}^{-1}$ in the fifth ratoon. It is necessary to mention here that the above cultivar and others released later in Louisiana (to be mentioned later) are all Type I as defined above and also a short growth cycle driven by temperate climate.

With the persistence of the interest in biomass energy [94], the traditional sugarcane breeding programs of US mainland proceeded with their energy cane breeding programs. As a result, the Louisiana program succeeded in releasing three cultivars $[72,95]$ and others are coming. In Florida, USA, the breeders also began the breeding of energy canes [38] and Legendre and Burner [37] found that first generation hybrids $\left(\mathrm{F}_{1}\right)$ are best suited for energy cane pointing out that backcrosses reduce biomass yield components and that the higher the number of backcrosses the higher that 
dilution. Korndorfer [80] found energy cane more appropriate than giant reed (Arundo donax L.) as a bioenergy feedstock in sandy soils of south Florida, and Duval et al. [96] found energy cane performing better in the spodosol (sandy soil) than in the histosols (muck soils) if $\mathrm{C}$ sequestration was taken into account. Additionally, Álvarez and Helsel [97] concluded that energy cane has potential to become a useful bioenergy crop in Florida's unmanaged mineral soils. Mark [98] and Brown [99] did breakeven economic analysis to guide Louisiana's growers if they are willing to adopt the new crop. Presently there is a joint effort by specialists from eight states of Southeastern USA to evaluate energy cane and other feedstocks, from field to industry [100]. They got encouraging results of yields from the experiments established north of the traditional sugarcane growing regions, at latitudes up to $33^{\circ} \mathrm{N}$ $[101,102]$. In their survey more than $1,500,000$ hectares was identified as potential locations to grow energy cane, which is almost twofold the area today devoted to sugarcane in continental USA [100].

In Barbados cultivars with more than $25 \%$ of fiber have been produced with the main objective of providing boiler fuel to be used in year-round generation of electricity [103]. Mauritius also developed a similar program [23]. However, in those programs, as with the pioneer work in Puerto Rico, they selected a type of cane which is producing more biomass and fiber but is still exploited in conventional sugar mills (Type I), producing syrup for ethanol production and surplus bagasse to be used in cogeneration. The further development of high fiber canes in Barbados will be returned later.

In Texas the biomass program of A\&M University has been attempting to make hybrids between Miscanthus and sugarcane [18, 104]; the "miscane," as coined by Jorge da Silva (personal communication), especially with resistance to frost, in order to allow its cultivation in higher latitudes than sugarcane is presently grown in continental USA, or to withstand the freezing winter temperatures in order to exploit the short crop cycle of sugarcane there [101, 102].

In Japan, S. spontaneum and Erianthus have been used to breed for high biomass cane and they succeeded in getting some outperforming cultivars $[64,105,106]$. In Thailand, high fiber canes are also being developed [107] and cultivars for marginal environments are being developed based on $S$. spontaneum germplasm collected within that country [108].

In Brazil, pioneer hybrids of energy cane were obtained by Canavialis, a private sugarcane breeding company. The energy cane hybrids were obtained by crossing S. officinarum types or commercial cultivars with $S$. spontaneum. In plant cane, the best clone produced $138 \%$ more total biomass (green matter) per area than a good conventional sugarcane variety and 235\% more fiber [109]. Vignis, a Brazilian private company established specifically to breed energy cane, is producing both Type I and Type II varieties, but mainly the latter one, from which bagasse is to be initially sold to feed boilers in food processing plants. Another Brazilian private company is also pursuing energy cane in order to feed its $2 \mathrm{G}$ ethanol plant, whereas a third one is looking to exploit the African market. The other traditional Brazilian sugarcane breeding programs, CTC, IAC, and RIDESA, are also pursuing energy cane cultivars to some extent.
Other sugarcane breeding centers around the world are probably initiating programs in energy cane, like Hawaii (Nagai, C., Personal communication).

\section{Some Important Characteristics of Energy Cane}

From afar, an energy cane field looks the same as a conventional sugarcane field. However on closer observation one can immediately perceive at least three strikingly different characteristics: a narrower leaf blade, a thinner stalk, and a more profuse tillering (the reference here is to a typical biomass producing energy cane (Type II) clones and the present day cultivars coming from crossings between $S$. officinarum varieties (commercial or not) and S. spontaneum. Other types of crosses can eventually give morphologically distinct plants; noteworthy is the fact that Barbados high fiber program has generated clones that look like conventional sugarcane clones but that are much more vigorous [110]. Typical Type II energy cane can be selected directly in the $\mathrm{F}_{1}$ or $\mathrm{BC}_{1}$ populations as backcross for sugar content is not necessary (selection of energy cane clones is usually made directly in $\mathrm{F}_{1}$ populations, and eventually $\mathrm{BC}_{1}$ populations, of crosses between a sugarcane type (complex Saccharum spp. plant) and an ancestral species like S. spontaneum, as the target is fiber or total biomass rather than sucrose. The wild ancestor contributes more to fiber content and biomass production and general adaptation to stressful conditions than sucrose content so, several backcrosses to S. officinarum are necessary if the intention is to breed a conventional high sucrose sugarcane variety. During the backcrossing process much of the original vigour from S. spontaneum is lost)). However, intrinsically there are many other traits that merit consideration.

One of the most prominent traits of energy canes is the high number of tillers per stool, not only in plant cane, but also in ratoons $([24,58,65,111])$. Closely related to number of tillers is the ratooning ability, both being very important in total yield over the whole cropping cycle. This last characteristic is very important both in economic and environmental terms (e.g., [67]). Usually, the higher the number of tillers the better the ratooning ability and this is pronounced in energy cane. At Vignis, selected individuals from $\mathrm{F}_{1}$ progeny produced a range of more than $200,000 \cdot \mathrm{ha}^{-1}$ calculated surviving tillers at adult phase to more than $400,000 \cdot \mathrm{ha}^{-1}$, a two- to fourfold increase over conventional sugarcane cultivars. These numbers are still greater in the first ratoon, for the same clones (Vignis, unpublished data). This characteristic is important not only for yield but also to increase the rate of multiplication, one of the significant economic constraints in the sugarcane cultivation (sugarcane crop is established through laying down stalks on the ground and subsequently chopping them into smaller pieces called setts or cuttings. Each internode of a stalk has one bud which sprouts after being covered by soil and forms a stool as result of the tillering process. Commercial cultivars produce in average $12 \mathrm{culms}$ per meter of row (conventional 1,50 interrow distance) with 15 buds each in 10-12-month-old cane which is suffice to 


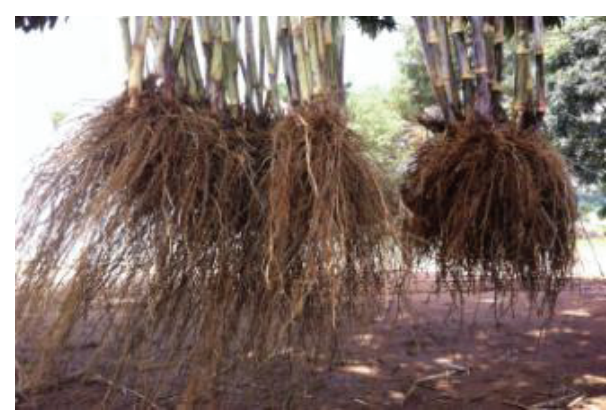

(a)

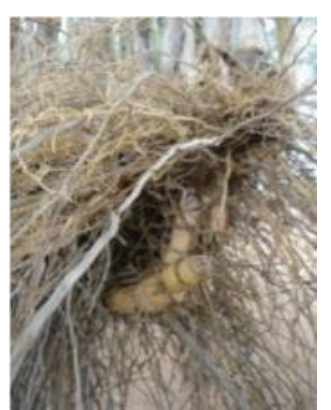

(b)

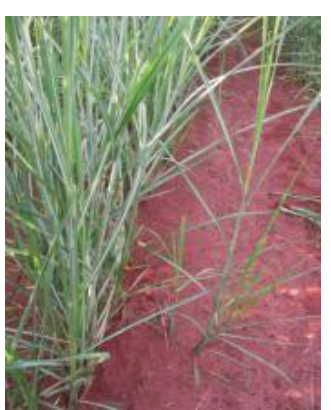

(c)

Figure 1: From left to right, a vigorous root system of energy cane at left compared to one of a commercial-type sugarcane at right; in the center, rhizomes can be seen under the same energy cane's clump; in the right, shoots emerging from the underground rhizome, distant from the original stool.

plant 10 hectares in the Brazilian traditional system. With the mechanical collection of stalks and subsequent mechanical planting the rate of multiplication is being reduced to as low as 50 to 60 percent of that value. This is one of the biggest factors of increasing cost of sugarcane crop nowadays. Energy cane, producing three- to fivefold more stalks than its counterpart, consequently gives a rate of multiplication commensurate with the increased stalk number. Additionally in the same conditions and on yearly basis, a good energy cane cultivar produces at least $50 \%$ more internodes per stalk and, consequently, buds, which also have better sprouting capacity (Vignis, unpublished data)). But high tillering ability is linked to another frequent characteristic of energy canes, the ability to produce rhizomes, a trait, originating from $S$. spontaneum, that merits further discussion.

Alexander [24] observed that the energy cane type produced an abundant and vigorous root system, surpassing the conventional cane in lateral extension, profundity in the soil profile, and also in volume; studies in Japan confirmed this characteristic $([105,112])$. This is a trait coming from S. spontaneum. More than 80 years ago [113] did the original study comparing root systems of S. officinarum, S. spontaneum, and $\mathrm{BC}_{2}$ commercial variety of that time (Co 281). They showed that $S$. officinarum had a superficial root system, $S$. spontaneum had a more vigourous and deeper system, and $\mathrm{BC}_{2}$ is an intermediate type (cited by [114]). At Vignis, more vigorous and profound root system of an energy cane compared to a conventional type cane has been confirmed [70]. However, more important is the ability to produce rhizomes that many types of $S$. spontaneum and other genera of the Saccharum complex have, but S. officinarum does not have $[49,57,115,116]$. Although Babu [115] inferred that rhizome formation is governed by a dominant gene, [59] found that it was expressed less in the $\mathrm{F}_{1}$ and may disappear after one to two backcrosses to S. officinarum. Walker [90] commented that managing interspecific hybrids in the field is difficult due to the rhizomatous habit derived from S. spontaneum. This suggests that Type I energy cane would have less rhizomatous habit than Type II, because the gene contribution of $S$. spontaneum is greatly reduced by the backcrosses used to generate it. This feature has also been observed at the Vignis' breeding program.
Rhizomes are organs found in many grass families that help their competitiveness in the wild. They confer the ability to overcome abiotic stress conditions, like water deficit or freezing temperatures, mainly providing the ability to regrow after die back of the aerial parts of the plant caused by any stressing agent (e.g., $[116,117])$. Both the vigorous root system and the presence of rhizomes in energy cane (Figure 1) [70] (Alexander had observed that his Type I energy cane showed the ability to produce outlying tillers, that is, tillers growing far from the original crown of the plant, but he did not report the actual existence of rhizome (see Alexander apud book, page 96, legend of Figures 5-4). As he managed a $\mathrm{BC}_{1}$ plant, probably the rhizomatous growth habit was modest and not very noticeable. Babu [115] considered the sprawlers originating from modified stalks growing below ground but not a true rhizome; J. Jeswiet (1925), in his key to distinguish the species of Saccharum, cited by Brandes [49], considered the "long subterranean runners" as a distinguishing characteristic of S. spontaneum and short runners as distinguishing characteristic of S. barberi and S. sinense. Modern studies are confirming claims that those latter two species are not true species and should rather be considered as horticultural groups (cultigens) that originated from natural crosses between S. officinarum and S. spontaneum (see revision in $[46,118])$. As such, it is reasonable to speculate that their shorter rhizomes are result of the dilution of the original rhizomatous trait of $S$. spontaneum) and are distinguishing characteristics that confer many practical advantages: (1) the plant tolerates drought stress better [111]; (2) the regrowth after the harvest is better [111, 119]; (3) the plant more efficiently exploits the soil resources [72]; (4) the protection of the soil against erosion is more efficient [120]; (5) rhizomes aid in sustainable ratooning, an important characteristic for economic and environmental reasons, as discussed elsewhere (e.g., $[121,122])$ and (6) there is a comparatively higher yield in most environments especially in marginal conditions of soil and climate (actually, all those characteristics are applied to selectable individuals in the population under selection. As indicated in the text, the diversity available in the germplasm bank is so big that the mating possibilities are enormous and, obviously, not all the families or individuals within a family are superior in all the desirable traits). 
Perennial plants usually possess a root system that is more profound than annuals and this has several advantages from the agronomical and environmental points of view (e.g., $[117,121,123])$. Profound root systems allow plants to avoid water stress during dry seasons, thus making the plant more amenable to be planted in marginal lands and so to not compete with food crops while bringing these areas into useful production. Abundant and vigorous root systems help mitigate soil erosion, one of the significant environmental problems in rural areas, by allowing prevention of water runoff and, thus, better water infiltration and also producing better soil structure (e.g., [117]). More water infiltration means more water conservation, an issue of great concern in many situations nowadays.

Profound root systems also encourage permanent sequestration of $\mathrm{C}$, as the roots below the arable profile are not recycled every time plowing is done [117]. That is one of the reasons perenniality is being looked for by some cereal breeders as a support for the 2 nd green revolution (e.g., $[117,121,123])$. It is worth mentioning, then, that energy cane, which could have a life cycle up to 10 years, $[37,60,72]$, in the long term requires fewer cultivation operations than conventional sugarcane, which is directly significant not only in economic terms but also in environmental terms [124].

\section{Dedicated Bioenergy Crops}

The global concern to seek sustainable and renewable energy has resuscitated interest in biomass energy as an important worldwide issue (e.g., $[29,30,94,125])$. To meet the enormous global demand on bioenergy in the midterm, either as natural biomass or transformed into liquid or gaseous forms, dedicated energy crops are considered as the source of feedstock for significantly substituting fossil fuel energy [17, 104]. Several dedicated energy crops are being studied beside sugarcane in Brazil and corn in the USA (e.g., [17, 104, 126128]). Climate acts as the main restraint in the choice of crop, and tropical and subtropical regions have advantages over temperate regions as in those zones $\mathrm{C}_{4}$ plants like sugarcane thrive better (e.g., $[17,18,129])\left(C_{3}\right.$ and $C_{4}$ photosynthesis are two processes that evolved in plants to synthesize carbon compounds (fix carbon dioxide). It is well established that the second process is more efficient particularly under both higher temperature and higher light conditions as found in the tropics and, thus, maintains optimal photosynthetic activity and consequently produces more biomass under stressful conditions. Many of the plants able to utilize $\mathrm{C}_{4}$ process are grasses like sugarcane. It should be mentioned that Miscanthus, a member of the Saccharum Complex and also a $\mathrm{C}_{4}$ plant, is adapted to temperate zones and, so, is being utilized as a bioenergy crop in Europe and is under extensive studies in the USA (e.g., $[17,18,104,128])$ ).

To be a viable option, a dedicated energy crop must fulfill several general requirements as listed and discussed below:

(1) having feedstock that must be easily and reliably transformed in useful forms of energy;

(2) high density of energy;

(3) high spatial density;
(4) year round availability;

(5) well-developed agronomic practices;

(6) favorable cost of production and delivery;

(7) perennial plant (renewable);

(8) being amenable to be produced under stress conditions and so not to compete with land used for food production;

(9) high favorable life cycle balance both of energy and GHG emissions.

To be thoroughly accepted and promptly adopted as an energy feedstock its direct use or the technology for its transformation in useful forms, if needed, must not require complicated or costly processes. The biomass also should have high energy density as this impacts several other factors, the lowest final cost of a unit of energy being the target; thus high productivity of dry matter per area is required. Sugarcane adequately fulfills those two categories. High spatial density implies the availability of land within a short radius from the processing or consuming facility. To be an economic alternative energy source in a long run the feedstock must be available all year-round. One of the weak points of annual crops is the seasonality and consequently short lived availability. Even conventional sugarcane has a harvest timeline dictated by the ripening and sugar accumulation, which is not the case of energy cane as the drive is fiber content, or ultimately biomass, and fiber does not vary during the course of the year as happens with sugar [81]; biomass accumulates with time and, so, in effect, it is stored in the field. A favorable cost of production and delivery is obviously a factor for any feedstock, which is influenced by a well-established agronomic production system, from planting to harvesting and delivery. Many potential feedstock options still require a lot of technological development, from breeding to end use, including production and harvest technologies. The breeding, planting, agronomy, harvest, and transport of sugarcanes are all well-established and understood technologies. It is advocated that energy crops must be grown in lands considered marginal for food production so as to not compete with food production. This is a reasonable and understandable position, although it must be kept in mind that quantity and final cost of food are determined by a complexity of factors. This is a discussion beyond the scope of this review and it suffices to note that energy cane is more resistant to stresses, as discussed earlier and thus is amenable to be planted in soils not suitable for food crops. Additionally, due to its high productivity compared to conventional sugar cane, it requires approximately twofold less land for the same final dry mass yield. Concerning the issue of sustainability and effective contribution to the mitigation of GHG, perennial plants like energy cane perform much better than annuals, as discussed elsewhere (e.g., $[96,117,121,123])$. If sugarcane has a GHG positive balance of $8-10: 1$ [10], it can be speculated that energy cane will have at least $20: 1$ balance as the dominating factor to that balance is the biomass productivity assuming all the other production factors would be equal. But, this value and all others reported in the literature are probably 
underestimated. Studies to determine the $\mathrm{C}$ fixation by the root system of energy cane, mainly of Type II, are still lacking, as is the added GHG benefits resulting from less disturbance of soil for replanting as a consequence of the longer ratoon cycles $[67,96]$.

So, energy cane fulfills all the requirements for a renewable bioenergy source. In conclusion, under tropical and subtropical conditions it has an unparalleled productivity, being able to produce more than $250 \mathrm{t} \cdot \mathrm{ha}^{-1} \cdot \mathrm{year}^{-1}$ of total green matter in rainfed (reasonable) conditions, or more than $60 \mathrm{t} \cdot \mathrm{ha}^{-1} \cdot$ year $^{-1}$ on a dry matter basis [24, 72], Vignis, unpublished data. In temperate regions, its performance will not be so good, as is also true for conventional sugarcane but the results in Florida and Louisiana confirm its comparative higher productivity and long-lasting ratoons compared to conventional sugarcane (remembering that they refer to Type I cultivars) $[37,72,81]$.

\section{Concluding Remarks}

It is worth it to state that although Alexander emphasized that the term "energy cane" should not apply to individual plants but rather to a management system, later on people used it to designate a specific type of sugarcane plant exploited for biomass production (e.g., [25]) and nowadays this is its common usage.

Although Alexander was unable to get his concepts adopted in Puerto Rico, his pioneer work remains central to what is taking place now. In his words, "for developing nations historically bound together with sugarcane there is still time for constructive and meaningful change. There is time to prepare its place as a future sugar crop, a domestic energy crop, and a multiple-products commodity in service to all future generations." And he proceeds stating "Toward this end, there is much to be learned from Puerto Rico's experience. Policy makers and planners alike are well advised to study it and to draw the necessary conclusions on behalf of their own sugar industries. It is the author's fondest hope that this book will assist materially all those who still respect the sugarcane plant, and who recognize its potential as a national resource of immensurable value." His strong statements sounded too revolutionary for that time. But are they convincing nowadays? It is understandable that for an industry aiming at recovering sugar it was hard to accept a feedstock with low sucrose content, low purity, and, simultaneously, high fiber. But now the overall outlook has changed. Besides ethanol, the bagasse, an undesirable waste at that time, is a valuable product today. As a complementary feedstock, energy cane can be utilized to attain both products, with the added advantage of increasing field productivity, mainly on lands not suitable for conventional cultivars (drier and lower fertility soils).

Increased productivity counteracts one of the main constraints today, the low sugarcane yield that is reducing the economic feasibility of many companies. Additionally, with at least three potential products, sugar, ethanol, and bagasse/energy, as in Brazil, it may now be the time to begin the transformation of cane production into a multiproduct enterprise. Byrt et al. [17], discussing the use of $\mathrm{C}_{4}$ plants as alternative biofuel feedstock, stated that "many promising energy crops appear to be overlooked, in particular variants of sugarcane and sweet sorghum" and continued that "the genetic complexity and narrow base of sugarcane present considerable challenges." Admittedly the wide variation within the sugarcane complex has largely been overlooked and the plant is genetically very complex indeed. But its narrow genetic base is only circumstantial and can be overcome with a specifically targeted program, as has been done in Barbados. In a long recurrent program for high sucrose content, materials with sucrose \% in cane between 19 and 22 and individuals with Brix as high as 30\% have been obtained [91]. Later on, crossing that population with other populations of a multipurposed cane or very high fiber [91, 103], individuals with Brix values between 19 and 23 combined with fiber \% values between 20 and 35 were obtained; the highest fiber value recorded was $42.6 \%$ with a Brix of 23.5 in the same individual [110]. This program exploited only a small fraction of all the genetic variability within the species S. spontaneum as a whole. Considering all the variabilities still available in that species, along with that in the Saccharum Complex, there are immense possibilities of new gene arrangements, probably not paralleled by any other group of plants. For the conventional sugarcane breeders there is no doubt that the challenges are great $[23,26,130]$, as sucrose accumulation in the stalks and the production of high biomass yield may be difficult to achieve within the conventional sugarcane germplasm [24, 41]. However, the work in Barbados suggests that this apparent negative association can be broken if a wide genetic base is used, followed by a long recurrent program [110]. The results so far obtained in Barbados by changing the target to total biomass production and exploiting all available genetic variation, both high sucrose and high fiber, give a clear indication of the potential of this approach to the production of biofuel types of cane.

Since the 1950s several expeditions supported by the ISSCT and other institutions have collected thousands of genotypes of the Saccharum complex from its centre of origin and of its centre of diversity. To give example, only considering the species S. spontaneum, there are more than 300 accessions in the World Collection of Sugarcane and Related Grasses maintained at the USDA-ARS National Clonal Germplasm Repository ([54]; T. Ayala, personal communication) and many more in the main collection maintained by the Sugarcane Breeding Institute, Coimbatore, India, plus their own SBI collection [52, 131, 132]; also, there are many accessions maintained by individual breeding programs in several countries (e.g., [87, 88, 90, 133-137]).

Among all the dedicated bioenergy crops so far analyzed, existing sugarcane cultivars are outstanding in terms of annual, renewable productivity per unit area, in terms of either wet or dry matter (e.g., $[3,138]$ ), and energy cane has the potential to produce two to three times more than this (e.g., [24, 37, 61, 72, 139]). As productivity is the main driver for the sustainability of any energy biomass source (economic, environmental, social, etc.), energy cane has the potential to effectively contribute to the world demand of 
bioenergy. Moreira [138] has suggested that sugarcane alone could supply the world expected increase in energy demand, oil, and electricity by 2030. If energy cane is developed and used instead of conventional sugarcane, his proposition would be much easier to attain, especially with the full development of the technology of second generation ethanol (e.g., $[81,96,140-143])$. But, ethanol is not the only combustible liquid that can be produced; jet fuel, biobutanol, biodiesel, biogas, methanol, syngas, and others are all forms of fuel that could potentially be obtained from energy cane (e.g., $[40,77,144])$. Beside fuels there are many other byproducts that could be produced from cane feedstock (e.g., [14, 40, 78, $145,146])$. In the meantime, bagasse is used as a combustible energy store, directly or as pellets, in industrial boilers and in thermoelectric plants and also as briquettes or pellets in heaters for small industries and households.

In Brazil, there is a big demand for bagasse as fuel to produce process vapor, mainly in food processing plants. The prospective demand from this market alone is more than $15 \mathrm{M}$ tons of bagasse annually and it is turning to be scanty at the mills as the surplus bagasse is also being used in cogeneration process. Demand for usage of bagasse in boilers of other industrial plants is also coming, as well as for the production of biofuels (pyrolisis), biogas, pellets, and paper board, to name a few, so that, as a dedicated biomass crop, energy cane has an enormous future potential, mainly for tropical countries like Brazil and Africa where appropriate agricultural land is still largely available [147-149]. Since energy cane is a new varietal concept, it is understandable that its contribution as a renewable bioenergy plant has been largely overlooked so far. But, due to its resemblance with sugarcane in terms of field management and feedstock industrialization and its recognizable value as a bioenergy plant, it is likely that its cultivation and exploitation will increase rapidly in the medium term future.

If the promises of practical benefits from GMO in sugarcane, as seems true, are a long way from being delivered in a form easily adopted by plant breeders, the contribution of energy cane will be real and realized in a relatively short term. It can be predicted that the possible gains attainable with it, in every sense, will be a breakthrough that parallels that attained by pioneer sugarcane breeders in Java when creating the hybrids that came to establish the modern sugarcane crop more than hundred years ago. This can be attained, quoting Berding et al. [150], "through application of the empirical art and experience of crop-improvement traditionalists."

\section{Conflict of Interests}

The authors declare that there is no conflict of interests regarding the publication of this paper.

\section{References}

[1] GIT, "Preface, A Symposium on World Energy Prospects," p. 1, Encyclopaedia Britannica, 1980.

[2] J. Coombs, "Sugar-cane as an energy crop," Biotechnology and Genetic Engineering Reviews, vol. 1, pp. 311-345, 1984.
[3] M. R. Xavier, The Brazilian Sugarcane Ethanol Experience, Issue Analysis, no. 3, Competitive Enterprise Institute, 2007.

[4] J. Goldemberg, "The Brazilian biofuels industry," Biotechnology for Biofuels, vol. 1, article 6, 2008.

[5] S. Matsuoka, J. Ferro, and P. Arruda, "The Brazilian experience of sugarcane ethanol industry," In Vitro Cellular and Developmental Biology: Plant, vol. 45, no. 3, pp. 372-381, 2009.

[6] M. F. Neves, M. J. A. Pinto, M. A. Coejero, and V. G. Trombin, Food and Fuel: The Example of Brazil, Wageningen Academic Publishers, Wageningen, The Netherlands, 2011.

[7] R. H. Mumm, P. D. Goldsmith, K. D. Rausch, and H. H. Stein, "Land usage attributed to corn ethanol production in the United States: sensitivity to technological advances in corn grain yield, ethanol conversion, and co-product utilization," Biotechnology for Biofuels, vol. 7, article 61, 2014.

[8] InterAcademy Council, "Lighting the way: toward a sustainable energy future," IAC Report, 2007.

[9] M. R. L. V. Leal and A. Da Silva Walter, "Sustainability of the production of ethanol from sugarcane: the Brazilian experience," International Sugar Journal, vol. 112, no. 1339, pp. 390-396, 2010

[10] I. C. Macedo and J. E. A. Seabra, "Mitigation of GHG emissions using sugarcane bioethanol," in Sugarcane Ethanol: Contribution to Climate Change Mitigation and the Environment, $\mathrm{P}$. Zuurbier and J. van der Vooren, Eds., pp. 95-111, Wageningen Academic, Wageningen, The Netherlands, 2008.

[11] I. C. Macedo, J. E. A. Seabra, and J. E. A. R. Silva, "Green house gases emissions in the production and use of ethanol from sugarcane in Brazil: the 2005/2006 averages and a prediction for 2020," Biomass and Bioenergy, vol. 32, no. 7, pp. 582-595, 2008.

[12] S. E. Lingle, "Sugar metabolism during growth and development in sugarcane internodes," Crop Science, vol. 39, no. 2, pp. 480-486, 1999.

[13] A. J. Waclawovsky, P. M. Sato, C. G. Lembke, P. H. Moore, and G. M. Souza, "Sugarcane for bioenergy production: an assessment of yield and regulation of sucrose content," Plant Biotechnology Journal, vol. 8, no. 3, pp. 263-276, 2010.

[14] A. P. de Souza, A. Grandis, D. C. C. Leite, and M. S. Buckeridge, "Sugarcane as a bioenergy source: history, performance, and perspectives for second-generation bioethanol," Bioenergy Research, vol. 7, no. 1, pp. 24-35, 2013.

[15] A. G. Alexander, Sugarcane Physiology: A study of the Saccharum Source-to-Sink System, Elsevier, Amsterdam, The Netherlands, 1973.

[16] J. E. Irvine, "Sugarcane," in Potential Productivity of Field Crops under Different Environments, W. H. Smith and S. J. Banta, Eds., pp. 361-381, IRRI, Los Baños, Philippines, 1983.

[17] C. S. Byrt, C. P. L. Grof, and R. T. Furbank, "C4 plants as biofuels feedstocks : optimising biomass production and feedstock quality from a lignocellulosic perspective," Journal of Integrative Plant Biology, vol. 53, no. 2, pp. 120-135, 2011.

[18] K. Jakob, F. Zhou, and A. H. Paterson, "Genetic improvement of C4 grasses as cellulosic biofuel feedstocks," In Vitro Cellular and Developmental Biology-Plant, vol. 45, no. 3, pp. 291-305, 2009.

[19] R. Ming, P. H. Moore, K.-K. Wu et al., "Sugarcane improvement through breeding and biotechnology," in Plant Breeding Reviews, J. Janick, Ed., vol. 27, chapter 2, pp. 15-118, 2006.

[20] T. V. Sreenivasan and N. V. Nair, Catalogue on Sugarcane Genetic Resources. III. Saccharum officinarum L., Sugarcane Breeding Institute, Coimbatore, India, 1991. 
[21] Y. J. Zhu, E. Komor, and P. H. Moore, "Sucrose accumulation in the sugarcane stem is regulated by the difference between the activities of soluble acid invertase and sucrose phosphate synthase," Plant Physiology, vol. 115, no. 2, pp. 609-616, 1997.

[22] A. D. H. Brown, "Correlation between Brix in juice and fibre in commercial hybrid sugar cane populations," Proceedings of the 12th Congress of the International Society of Sugarcane Technologists, vol. 12, pp. 754-759, 1965.

[23] K. Ramdoyal and G. H. Badaloo, "Prebreeding in sugarcane with an emphasis on the programme of the Mauritius Sugar Industry Research Institute," in Managing Plant Genetic Diversity, J. M. M. Engels, V. R. Rao, A. H. D. Brown, and M. T. Jackson, Eds., pp. 307-321, IPGRI, 2002.

[24] A. G. Alexander, The Energy Cane Alternative, Elsevier, Amsterdam, The Netherlands, 1985.

[25] T. L. Tew and R. M. Cobil, "Genetic improvement of sugarcane ( Saccharum spp.) as an energy crop," in Genetic Improvement of Bioenergy Crops, W. Vermerris, Ed., pp. 249-272, Springer, 2008.

[26] W. L. Burnquist, "Sugarcane research and development: a view from the private sector," in Proceedings of the Congress of the International Society of Sugar Cane Technologists, vol. 28, pp. 18, 2013.

[27] A. G. Alexander, "Energy cane as a multiple-products alternative," in Proceedings of the Post-Conference Seminar, Aiea Library, p. 17, Hawaii Natural Energy Institute, Aiea, Hawaii, USA, November 1984.

[28] R. Rosillo-Calle, "Overview of bioenergy," in The Biomass Assessment Handbook: Bioenergy for a Sustainable Environment, R. Rosillo-Callé, R. Rosillo-Calle, P. Groot et al., Eds., pp. 1-23, Earthscan, 2007.

[29] U.S. DOE, "Biomass. Multi-year Program Plan. Office of the Biomass Program, Energy Efficiency and Renewable Energy," U.S. Department of Energy, 2008, http://wwwl.eere.energy .gov/bioenergy/pdfs/mypp_april_2011.pdf.

[30] WGBU, "Future Bioenergy and Sustainable Land Use. Summary for Policy Makers. German Advisory Council of Global Change," 2013, http://www.wbgu.de/fileadmin/templates/dateien/veroeffentlichungen/hauptgutachten/jg2008/wbgu_jg2008_ en.pdf.

[31] G. Samuels, A. G. Alexander, C. Rios, and M. Garcia, "The production of energy cane in Puerto Rico: the Hatillo project," in Proceedings of the Congress of the International Society of Sugar Cane Technologists, vol. 3, pp. 14-17, 1984.

[32] B. Bridgman, M. Maio Schimitz Jr., and A. Teixeira, "What ever happened to the Puerto Rican sugar manufacturing industry?" Staff Report 44, Federal Reserve Bank of Minneapolis, 2012, http://www.minneapolisfed.org/research/sr/sr477.pdf.

[33] J. E. Badillo, “The sugar industry of Puerto Rico," 2012, http://www.preb.com/apuntes5/\%20sugarind.html.

[34] A. G. Alexander, "Sugarcane as a source of biomass," in Sugarcane as Feed, R. Sansourcy, G. Aarts, and T. R. Preston, Eds., FAO Corporate Document Repository, Rome, Italy, 1988, http://www.fao.org/docrep/003/s8850e/S8850E04.htm.

[35] R. P. Humbert, "The growing of sugar cane for energy," The Sugar Journal, pp. 19-22, 1980.

[36] S. Matsuoka and H. Arizono, "Avaliação de variedades pela capacidade de produção de biomassa e pelo valor energetico," STAB, vol. 6, no. 2, pp. 39-46, 1987 (Portuguese).

[37] B. L. Legendre and D. M. Burner, "Biomass production of sugarcane cultivars and early-generation hybrids," Biomass \& Bioenergy, vol. 8, no. 2, pp. 55-61, 1995.
[38] P. Mislevy, F. G. Martin, M. B. Adjei, and J. D. Miller, "Agronomic characteristics of US 72-1153 energycane for biomass," Biomass \& Bioenergy, vol. 9, no. 6, pp. 449-457, 1995.

[39] M. R. L. V. Leal, "The potential of sugarcane as an energy source," in Proceedings of the 26th Congress, International Society of Sugar Cane Technologists, pp. 23-34, Durban, South Africa, July 2007.

[40] P. W. Rein, "Prospects for the conversion of a sugar mill into a biorefinery," in Proceedings of the Congress of the International Society of Sugar Cane Technologists, vol. 26, pp. 44-60, 2007.

[41] F. C. Botha, "Energy yield and cost in a sugarcane biomass system," in Proceedings of the Australian Society of Sugar Cane Technologists, vol. 31, pp. 1-10, 2009.

[42] K. R. Woodard and G. M. Prine, "Dry matter accumulation of elephant grass, energycane and elephantmillet in a subtropical climate," Crop Science, vol. 33, pp. 818-824, 1993.

[43] P. Lakshmanan, R. J. Geijskes, K. S. Aitken, and et al, "Sugarcane biotechnology: the challenges and opportunities," In Vitro Cellular \& Developmental Biology-Plant, vol. 41, pp. 345-363, 2005.

[44] M. Kim and D. F. Day, "Composition of sugar cane, energy cane, and sweet sorghum suitable for ethanol production at Louisiana sugar mills," Journal of Industrial Microbiology and Biotechnology, vol. 38, no. 7, pp. 803-807, 2011.

[45] G. Piperidis, N. Piperidis, and A. D’Hont, “Molecular cytogenetic investigation of chromosome composition and transmission in sugarcane," Molecular Genetics and Genomics, vol. 284, no. 1, pp. 65-73, 2010.

[46] P. H. Moore, A. H. Paterson, and T. Tew, "Sugarcane: the crop, the plant, and domestication," in Sugarcane: Physiology, Biochemistry and Functional Biology, P. H. Moore and F. C. Botha, Eds., pp. 1-17, John Wiley \& Sons, 2013.

[47] A. Selvi, N. V. Nair, J. L. Noyer et al., "Genomic constitution and genetic relationship among the tropical and subtropical Indian sugarcane cultivars revealed by AFLP," Crop Science, vol. 45, no. 5, pp. 1750-1757, 2005.

[48] P. A. Jackson, "Breeding for improved sugar content in sugarcane," Field Crops Research, vol. 92, no. 2-3, pp. 277-290, 2005.

[49] E. W. Brandes, "Origin, dispersal and use in breeding of the Melanesian garden sugarcanes and their derivative, Saccharum officinarum L," in Proceedings of the 6th Congress, International Society of Sugar Cane Technologists, vol. 9, pp. 709-750, 1956.

[50] G. C. Stevenson, Genetics and Breeding of Sugarcane, London, UK, Longman, 1965.

[51] R. R. Panje, "Studies in Saccharum spontaneum and allied grasses. 3. Recent exploration for Saccharum spontaneum and related grasses in India," in Proceedings of the 8th Congress of the International Society of Sugar-Cane Technologists, vol. 8, pp. 491503, 1954.

[52] N. Berding and B. T. Roach, "Germplasm collection, maintenance, and use," in Sugarcane Improvement through Breeding, D. J. Heinz, Ed., pp. 143-210, Elsevier, Amsterdam, The Netherlands, 1987.

[53] B. T. Roach, "Origin and improvement of the genetic base of sugarcane," in Proceedings of the Congress of the International Society of Sugar Cane Technologists, vol. 11, pp. 34-47, 1989.

[54] P. Y. P. Tai, J. D. Miller, and B. L. Legendre, "Evaluation of the world collection of Saccharum spontaneum L.," in Proceedings of the Congress of the International Society of Sugar Cane Technologists, vol. 22, pp. 250-260, 1996, http://ethanolrfa.3cdn.net/ d9d44cd750f32071c6_h2m6vaik3.pdf. 
[55] S. Price, "Interspecific hybridization in sugarcane," in Proceedings of the Congress of the International Society of Sugar Cane Technologists, vol. 12, pp. 1021-1026, 1965.

[56] B. T. Roach and J. Daniels, "A review of the origin and improvement of sugarcane," in Proceedings of the International Sugarcane Breeding Workshop, pp. 1-31, Copersucar, São Paulo, Brazil, 1987.

[57] B. T. Roach, "Quantitative effects of hybridization in Saccharum officinarum x Saccharum spontaneum crosses," in Proceedings of the International Society of Sugar Cane Technologists, vol. 13, pp. 939-954, 1969.

[58] L. Wang, P. A. Jackson, X. Lu et al., "Evaluation of sugarcane $\mathrm{x}$ Saccharum spontaneum progeny for biomass composition and yield components," Crop Science, vol. 48, no. 3, pp. 951-961, 2008.

[59] B. T. Roach, "Utilization of Saccharum spontaneum in sugarcane breeding," in Proceedings of the 16th Congress of the International Society of Sugar Cane Technologists, vol. 16, pp. 43$58,1978$.

[60] M. Giamalva, S. Clark, and J. Stein, "Sugarcane hybrids of biomass," Biomass, vol. 6, pp. 61-68, 1984.

[61] M. Giamalva, S. Clark, and J. Stein, "Conventional vs high fiber sugarcane," Journal of the American Society of Sugar Cane Technologists, vol. 4, pp. 106-109, 1985.

[62] K. Ramdoyal and G. H. Badaloo, "An evaluation of interspecific families of different nobilised groups in contrasting environments for breeding novel sugarcane clones for biomass," in Proceedings of the International Society of Sugar Cane Technologists Conference, vol. 26, pp. 632-645, 2007.

[63] P. Y. P. Tai, H. He, H. Gan, and J. D. Miller, "Variation for juice quality and fiber content in crosses between sugarcane and related grasses," Journal of the American Society of Sugar Cane Technologists, vol. 12, pp. 47-57, 1992.

[64] Y. Terajima, M. Matsuoka, K. Ujihara et al., "The simultaneous production of sugar and biomass ethanol using high-biomass sugarcane derived from interspecific and intergeneric cross in Japan," in Proceedings of the Biomass Asia Workshop, Tokyo, Japan, 2005.

[65] K. C. Shang, P. Y. Juang, T. L. Chu, and S. T. Huang, "A study on the transmission of some important characteristics of Taiwan originated wild cane (Saccharum spontaneum L.)," in Proceedings of the 13th Congress of the International Society of Sugar Cane Technologists, pp. 968-974, 1969.

[66] S. B. Milligan, K. A. Gravois, K. P. Bischoff, and F. A. Martin, "Crop effects on genetic relationships among sugarcane traits," Crop Science, vol. 30, pp. 927-931, 1990.

[67] S. Matsuoka and R. Stolf, "Sugarcane tillering and ratooning: key factors for a profitable cropping," in Sugarcane: Production, Cultivation and Uses, J.F. Goncalves and K. D. Correia, Eds., pp. 137-157, Nova, New York, NY, USA, 2012.

[68] W. F. Allison, "Effect of extraneous material and fiber in sugarcane on the sugar extraction and recovery," in Proceedings of the 6th Congress, International Society of Sugar Cane Technologists, vol. 16, pp. 2173-2178, 1978.

[69] K. A. Gravois and S. B. Milligan, "Genetic relationship between fiber and sugarcane yield components," Crop Science, vol. 32, pp. 62-67, 1992.

[70] S. Matsuoka, "Sobre o sistema radicular da cana-de-açúcar," STAB, vol. 31, no. 6, pp. 66-67, 2013 (Portuguese).

[71] N. Dharmawardene, "Sustainable sugarcane ratoon management," in Sugar Cane: Production Management and AgroIndustrial Imperatives, S. Solomon, S. S. Grewal, Y.-R. Li, R.
C. Magarey, and G.P. Rao, Eds., pp. 95-141, International Book Distributing, Mumbai, India, 2005.

[72] K. P. Bischoff, K. A. Gravois, T. E. Reagan et al., "Registration of "L79-1002" sugarcane," Journal of Plant Registrations, vol. 2, pp. 211-217, 2008.

[73] D. Santchurn, K. Ramdoyal, M. G. H. Badaloo, and M.T. Labuschagne, " From sugar industry to cane industry: evaluation and simultaneous selection of different types of high biomass canes," Biomass and Bioenergy, pp. 82-92, 2014.

[74] S. Arni and A. Converti, "Conversion of sugarcane bagasse into a resource," in Sugarcane. Production, Cultivation and Uses, J. E. Goncalves and K. D. Correia, Eds., pp. 285-301, Nova Publishers, New York, NY, USA, 2012.

[75] M. Koller, A. Salerno, A. Reiterer et al., "Sugarcane as feedstock for biomediated polymer production," in Sugarcane: Production, Cultivation and Uses, J. F. Goncalves and K. D. Correia, Eds., pp. 105-136, Nova Publishers, New York, NY, USA, 2012.

[76] D. R. Mulinari, M. R. Capri, and T. F. Maia, "Use of sugarcane bagasse in thermoplastics and thermosetting composites," in Sugarcane. Production, Cultivation and Uses, J. F. Goncalves and K. D. Correia, Eds., pp. 187-214, Nova Publishers, New York, NY, USA, 2012.

[77] L. Tao and A. Aden, "The economics of current and future biofuels," In Vitro Cellular and Developmental Biology, vol. 45, no. 3, pp. 199-217, 2009.

[78] I. M. O’Hara, Z. Zhang, D. W. Rackemann et al., "Prospects for the development of sugarcane biorefineries," in Proceedings of the 28th Congress, International Society of Sugar Cane Technologists Conference, Sao Paulo, Brazil, May 2013.

[79] J. Wang, S. Nayak, K. Koch, and R. Ming, "Carbon partitioning in sugarcane (Saccharum species)," Frontiers in Plant Science, vol. 4, article 201, pp. 1-6, 2013.

[80] P. H. Korndorfer, Biomass and energy yields of bioenergy germplasm grown on sandy soils in Florida [M.S. thesis], University of Florida, 2011, http://ufdcimages.uflib.ufl.edu/UF/ E0/04/30/46/00001/korndorfer_p.pdf.

[81] J. E. Knoll, W. F. Anderson, E. P. Richard et al., "Harvest date effects on biomass quality and ethanol yield of new energycane (Saccharum hyb.) genotypes in the Southeast USA," Biomass and Bioenergy, vol. 56, pp. 147-156, 2013.

[82] D. G. Christian, A. B. Riche, and N. E. Yates, "Growth, yield and mineral content of Miscanthus $\times$ giganteus grown as a biofuel for 14 successive harvests," Industrial Crops and Products, vol. 28, no. 3, pp. 320-327, 2008.

[83] J. Daniels and B. T. Roach, "Taxonomy and evolution," in Sugarcane Improvement through Breeding, D. J. Heinz, Ed., pp. 7-84, Elsevier, Amsterdam, The Netherlands, 1987.

[84] C. C. Lo, Y. H. Chen, Y. J. Huang, and S. C. Shih, "Recent progress in Miscanthus nobilization program," in Proceedings of the International Society of Sugar Cane Technologists, vol. 19, pp. 514-521, 1986.

[85] D. I. T. Walker, "Utilization of noble and S. spontaneum germplasm in the West Indies," in Proceedings of the Congress of the International Society of Sugar Cane Technologists, vol. 14, pp. 224-232, 1971.

[86] P. Y. P. Tai, H. Gan, H. He, and J. D. Miller, "Phenoyipic characteristics of $\mathrm{F} 2$ and $\mathrm{BC} 1$ progenies from sugarcane intergeneric crosses," Journal of American Society of Sugar Cane Technologists, vol. 11, pp. 38-47, 1991.

[87] A. J. Kennedy, "Genetic base broadening in the West Indies Sugar Cane Breeding Programme by the incorporation of wild 
species," in Broadening the Genetic Base of Crop Production, H. D. Cooper, C. Spillane, and T. Hodgkin, Eds., pp. 283-294, IPGRI/FAO/CABI, 2001.

[88] G. Sukarso and P. D. N. Mirzawan, "World germplasm repository of Saccharum species," in Sugar Cane: Production Management and Agro-Industrial Imperatives, S. Solomon, S. S. Grewal, Y.-R. Li et al., Eds., pp. 465-484, International Book Distributing Co., Lucknow, India.

[89] D. J. Heinz, "Sugarcane improvement: current productivity and future opportunities," in Proceedings of the International Sugarcane Breeding Workshop, pp. 55-70, Copersucar, São Paulo, Brazil, 1987.

[90] D. I. T. Walker, "Manipulating the genetic base of sugarcane," in Proceedings of the Copersucar International Sugarcane Breeding Workshop, pp. 321-334, São Paulo, Brazil, 1987.

[91] A. J. Kennedy, "Breeding improved cultivars for the Caribbean by utilization of total biomass production," in Proceedings of the International Society of Sugarcane Technologists Conference, vol. 25, pp. 491-499, 2005.

[92] G. Samuels and P. Jawetz, Energy Cane: A New Future for Sugarcane, 2011.

[93] G. Eggleston, M. Salassi, E. Richard, and H. Birkett, "Sustainability of the sugar industry: Future value addition from sugarcane," vol. 109, pp. 415-416, 418, 420-422, 424, 426, 430, 432, 2007.

[94] US DOE, "Billion-Ton Update. Biomass Supply for a Bioenergy and Bioproducts Industry," Oak Ridge National Laboratory, Oak Ridge, Tenn, USA, 2011, http://bioenergykdf.net.

[95] T. L. Tew, R. Cobill, E. Richard, and K. Gravois, "Registration of three high fiber sugar cane cultivars, L 79-1002, HoCP 91-552 and Ho 00-961, for biofuels production," in Proceedings of the ASA-CSSA-SSSA International Annual Meeting, November 2007, https://crops.confex.com/crops/2007am/techprogram/ P37536.HTM.

[96] B. D. Duval, K. S. Anderson-Teixeira, S. C. Davis et al., "Predicting greenhouse gas emissions and soil carbon from changing pasture to an energy crop," PLoS ONE, vol. 8, no. 8, Article ID e72019, 2013.

[97] J. Álvarez and Z. R. Helsel, Economic Feasibility of Biofuel Crops in Florida: Energycane on Mineral Soils, 2011, http://edis .ifas.ufl.edu/SC089.

[98] T. B. Mark, Cellulosic ethanol in Louisiana: a three part economic analysis of feedstocks, pricing strategies and location strategies [Ph.D. dissertation], Department of Agricultural Economics and Agribusiness, Louisiana State University, 2010.

[99] K. Brown, The economic feasibility of utilizing energy cane in the cellulosic production of ethanol [M.S. thesis], Agricultural and Mechanical College, Louisiana State University, 2012.

[100] SUBI, A Regional Program for Production of Multiple Agricultural Feedstocks and Processing to Biofuels and Biobased Chemicals, Sustainable Bioproducts Inititative, 2012.

[101] E. Richard Jr., T. Tew, R. Cobill, and A. L. Hale, "Sugar/energy canes as feedstocks for the biofuels industry," in Proceedings of the Short Rotation Crops International Conference, p. 47, 2010, http://www.nrs.fs.fed.us/pubs/gtr/gtr_nrs-p-31/47richard-p-31pdf.

[102] R. Viator, P. White, and E. Richard Jr., "Sustainability production of energycane for bio-energy in the Southeastern United States," in Sustainability of the Sugar and Sugar-Ethanol Industries, G. Eggleston, Ed., vol. 1058 of ACS Symposium Series, pp. 147-161, 2010.
[103] P. S. Rao, H. Davis, and C. Simpson, "New sugarcane cultivars and year round sugar and ethanol production with bagassebased cogeneration in Barbados and Guiana," Proceedings of the 2007 Congress, International Society of Sugar Cane Technologists, vol. 26, pp. 1169-1176, 2007.

[104] R. W. Jessup, "Development and status of dedicated energy crops in the United States," In Vitro Cellular \& Developmental Biology-Plant, vol. 45, no. 3, pp. 282-290, 2009.

[105] Y. Terajima, A. Sugimoto, S. Fukuhara et al., "The feature of root growth and activity of a high yielding interspecific hybrid between Saccharum hybrid and S. spontaneum L.," in Proceedings of the 25th Congress of the International Society of Sugar Cane Technologists, pp. 255-258, 2005.

[106] A. Sugimoto, Y. Terajima, T. Terauchi et al., "Developing new types of sugarcane by hybridization between commercial sugarcane cultivars and wild relatives," in Proceedings of the Symposium FAO RAP-NIAS, vol. 2012/1, pp. 11-24, Tsukuba, Japan, October 2012.

[107] M. S. Rao and P. Weerathaworn, "Diversification of breeding program to develop multipurpose sugarcane cultivars," Sugar Tech, vol. 11, no. 1, pp. 77-79, 2009.

[108] W. Ponragdee, S. Ohara, S. Sansayawichai et al., "New type of high yielding sugarcane with lower sugar and higher fibre content suitable for stable co-production of sugar and ethanol for Northeast Thailand," in Proceedings of the Congress of the International Society of Sugar Cane Technologists, vol. 28, p. 12, USB Storage, 2013.

[109] S. Matsuoka, J. Bressiani, W. Maccheroni, and I. Fouto, "Sugarcane bioenergy," in Sugarcane. Bioenergy, Sugar and EthanolTechnology and Prospects, F. Santos, A. Borém, and C. Caldas, Eds., pp. 471-500, MAPA/ACS: UFV/DEA, Brasilia, Brazil, 2012.

[110] A. J. Kennedy, "Prospects for combining high sucrose content with increased fibre to generate multi-purpose cane varieties," in Proceedings of the Conference of West Indies Sugar Technologists, Jamaica, April 2008.

[111] R. R. Panje, "The role of Saccharum spontaneum in sugarcane breeding," in Proceedings of the 14th Congress of the International Society of Sugar Cane Technologists, vol. 14, pp. 217-233, 1972.

[112] T. Sakaigaichi, Y. Terajima, T. Terauchi, A. Sugimoto, N. Kato, and M. Matsuoka, "Effect of dense planting on the growth and yield of forage sugarcane variety, KRFo93-1, in planting cane," Japanese Journal of Crop Science, vol. 79, no. 1, pp. 1-9, 2010 (Japanese).

[113] T. S. Venkatraman and R. Thomas, "Studies of sugarcane roots at different stages of growth," Memoirs of the Department of Agriculture in India, Botanical Series, vol. 16, no. 5, pp. 145-157, 1929.

[114] P. H. Moore, "Anatomy and morphology", in Sugarcane Improvement through Breeding, D. J. Heinz, Ed., pp. 85-142, Elsevier, Amsterdam, The Netherlands, 1987.

[115] C. N. Babu, "Genetical studies in Saccharum spontaneum. I. Inheritance of habit and occurrence of sprawlers," in Proceedings of the International Society of Sugar Cane Technologists (ISSCT '65), 1965.

[116] A. H. Paterson, "Rhizomatouness: genes important for a weediness syndrome," in Weeding and Invasive Plant Genomes, C. Steward Jr., Ed., pp. 99-109, Wiley, 2009.

[117] D. B. Kell, "Breeding crop plants with deep roots: their role in sustainable carbon, nutrient and water sequestration," Annals of Botany, vol. 108, no. 3, pp. 407-418, 2011. 
[118] S. Reed, T. Ayala-Silva, S. Brown, B. Glaz, and J. Comstock, "Screening Saccharum barberi and sinense accessions for flood tolerance and biomass production," Journal of Agronomy and Crop Science, vol. 198, no. 3, pp. 236-244, 2012.

[119] Y. Terajima, M. Matsuoka, S. Irei et al., "Breeding for highbiomass sugarcane and its utilization in Japan," in Proceedings of the 26th Congress of the International Society of Sugar Cane Technologists, vol. 26, pp. 161-162, 1997.

[120] G. Gyssels, J. Poesen, E. Bochet, and Y. Li, "Impact of plant roots on the resistance of soils to erosion by water: a review," Progress in Physical Geography, vol. 29, no. 2, pp. 189-217, 2005.

[121] J. D. Glover, C. M. Cox, and J. P. Reganold, "Future farming: a return to roots?" Scientific American, vol. 297, no. 2, pp. 82-89, 2007.

[122] S. Matsuoka and A. A. F. Garcia, "Sugarcane underground organs: going deep for sustainable production," Tropical Plant Biology, vol. 4, no. 1, pp. 22-30, 2011.

[123] J. D. Glover, J. P. Reganold, L. W. Bell et al., "Increased food and ecosystem security via perennial grains," Science, vol. 328, no. 5986, pp. 1638-1639, 2010.

[124] D. R. Montgomery, "Soil erosion and agricultural sustainability," Proceedings of the National Academy of Sciences of the United States of America, vol. 104, no. 33, pp. 13268-13272, 2007.

[125] NREL, The Biomass Economy, 2002, http://www.wcsen.org/ Workshops/EnergizeYourClassroomWithSTEM/USBMemory/ Information\%20About\%20Alternative\%20Energy/NREL\%20\%20The\%20Biomass\%20Economy.pdf.

[126] J. M-F. Johnson, M. D. Coleman, R. Gesch et al., "Biomassbioenergy crops in the United States: a changing paradigm," The American Journal of Plant Science and Biotechnology, vol. 1, no. 1, pp. 1-28, 2007.

[127] J. L. Gonzalez-Hernandez, G. Sarath, J. M. Stein, V. Owens, K. Gedye, and A. Boe, "A multiple species approach to biomass production from native herbaceous perennial feedstocks," In Vitro Cellular and Developmental Biology-Plant, vol. 45, no. 3, pp. 267-281, 2009.

[128] C. Somerville, H. Youngs, C. Taylor, S. C. Davis, and S. P. Long, "Feedstocks for lignocellulosic biofuels," Science, vol. 329, no. 5993, pp. 790-792, 2010.

[129] R. F. Sage and X. Zhu, "Exploiting the engine of C4 photosynthesis," Journal of Experimental Botany, vol. 62, no. 9, pp. 29893000, 2011.

[130] M. Dal-Bianco, M. S. Carneiro, C. T. Hotta et al., "Sugarcane improvement: how far can we go?" Current Opinion in Biotechnology, vol. 23, no. 2, pp. 265-270, 2012.

[131] K. M. Naidu and T. V. Sreenivasan, "Conservation of sugarcane germplasm," in Proceedings of the Copersucar International Sugarcane Breeding Workshop, pp. 33-53, 1987.

[132] SBI-Sugarcane Breeding Institute, Germplasm Collections, 2013, https://www.sugarcane.res.in/index.php/resrch/geneticresources.

[133] G. P. Oramas, N. B. Liranza, A. C. Martin et al., Recursos Genéticos de la Caña de Azúcar, IMAGO, Havana, Cuba, 1997.

[134] H. Shunchang, Y. Qinghui, and X. Fenghui, "Collection and description of basic germplasm of sugarcane (Saccharum Complex) in China," International Sugar Journal, vol. 1201, pp. 84-93, 1999.

[135] H. Chen, Y. Fan, Q. Cai, and Y-P. Zhang, "Research on genetic diversity and phylogeny of Saccharum spontaneum L. in China," in Proceedings of the 4th International Crop Science Congress, Brisbane, Australia, September 2004.
[136] J. A. Arro, J. C. Veremis, C. A. Kimbeng, and C. Botanga, "Genetic diversity and relatioships revealed by AFLP markers among Saccharum spontaneum and related species and genera," Journal American Society of Sugar Cane Technologists, vol. 26, pp. 101-115, 2006.

[137] S. Nagatomi and K. Degi, "Collection and description of wild sugarcane species indigenous to Japan," Proceedings of the International Society of Sugar Cane Technologists, vol. 26, pp. 745749, 2007.

[138] J. R. Moreira, "Global biomass energy potential," Mitigation and Adaptation Strategies for Global Change, vol. 11, no. 2, pp. 313333, 2006.

[139] D. M. Burner and B. L. Legendre, "Phenotypic variation of biomass yield components in $\mathrm{F}_{1}$ hybrids of elite sugarcane crossed with Saccharum officinarum and S. spontaneum," Journal of the American Society of Sugar Cane Technologists, vol. 20, pp. 81-87, 2000.

[140] R. E. H. Sims, W. Mabee, J. N. Saddler, and M. Taylor, "An overview of second generation biofuel technologies," Bioresourc Technology, vol. 101, no. 6, pp. 1570-1580, 2010.

[141] S. Shields and R. Boopathy, "Ethanol production from lignocellulosic biomass of energy cane," International Biodeterioration \& Biodegradation, vol. 65, no. 1, pp. 142-146, 2011.

[142] AEC-Advanced Ethanol Council, "Cellulosic Ethanol Report 2012-2013," http://ethanolrfa.3cdn.net/d9d44cd750f32071c6_ h2m6vaik3.pdf.

[143] V. Balan, D. Chiaramonti, and S. Kumar, "Review of US and EU initiatives toward development, demonstration, and commercialization of lignocellulosic biofuels," Biofuels, Bioproducts \& Biorefining, vol. 7, no. 6, pp. 732-759, 2013.

[144] D. F. Day, "Why ethanol? Butanol production and the raw mill," Journal American Society Sugar Cane Technologists, vol. 30, p. $161,2010$.

[145] M. A. Godshall, "Bio-recycling of cellulosic residues of sugarcane to augment their agro-industrial value," in Proceedings of the International Symposium on Sustainable Sugarcane Sugar Production Technology, pp. 657-663, Nanning, China, 2004.

[146] H. P. Blaschek, "The journey to the next-generation of bioeconomy. The US perspective," in Energy, Bio Fuels and Development. Comparing Brazil and the United States, E. Amann, W. Baer, and D. V. Coes, Eds., pp. 197-202, Routledge, New York, NY, USA, 2011.

[147] C. V. Manzatto, E. D. Assad, J. F. M. Bacca et al., Zoneamento Agroecológico da Cana-de-Açúcar, EMBRAPA, MAPA, Rio de Janeiro, Brazil, 2009, (Portuguese).

[148] G. Fischer and L. Schrattenholzer, "Global bioenergy potentials through 2050," Biomass and Bioenergy, vol. 20, no. 3, pp. 151-159, 2001.

[149] H. Haberl, K. Erb, F. Krausmann et al., "Global bioenergy potentials from agricultural land in 2050: sensitivity to climate change, diets and yields," Biomass and Bioenergy, vol. 35, no. 12, pp. 4753-4769, 2011.

[150] N. Berding, M. Hogarth, and M. Cox, "Plant improvement of sugarcane," in Sugarcane, G. L. James, Ed., pp. 20-53, Blackwell Science, Oxford, UK, 2nd edition, 2004. 

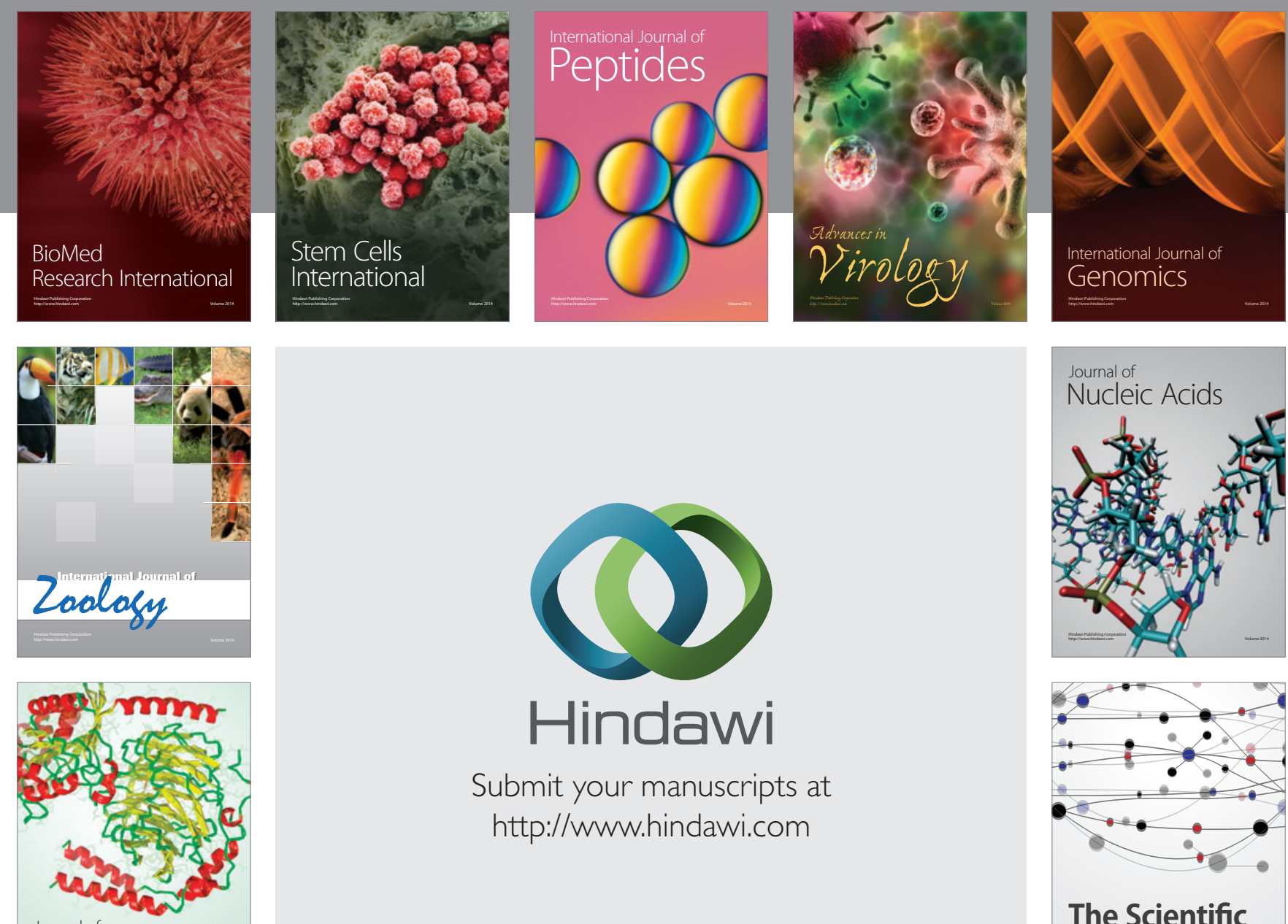

Submit your manuscripts at

http://www.hindawi.com

Journal of
Signal Transduction
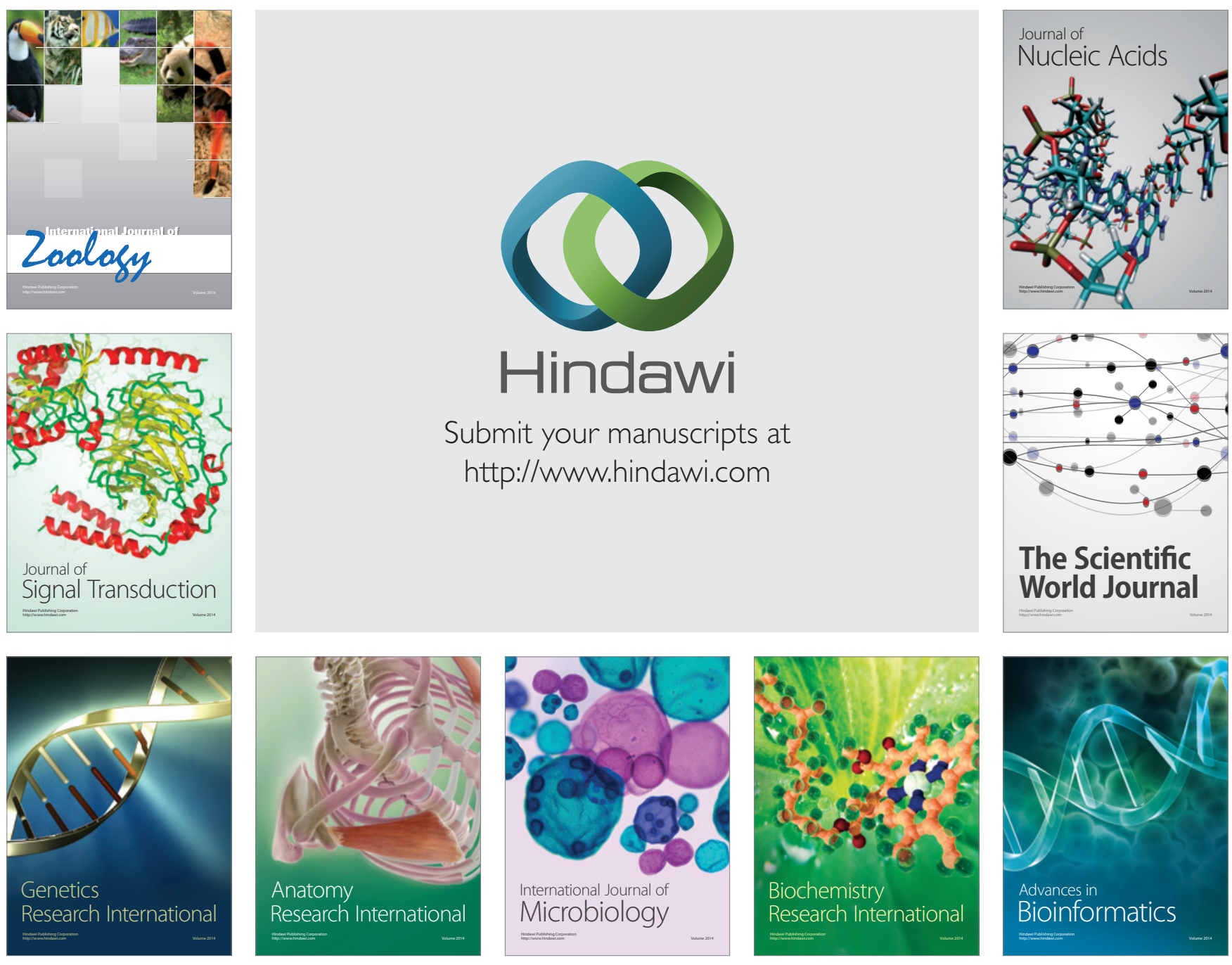

The Scientific World Journal
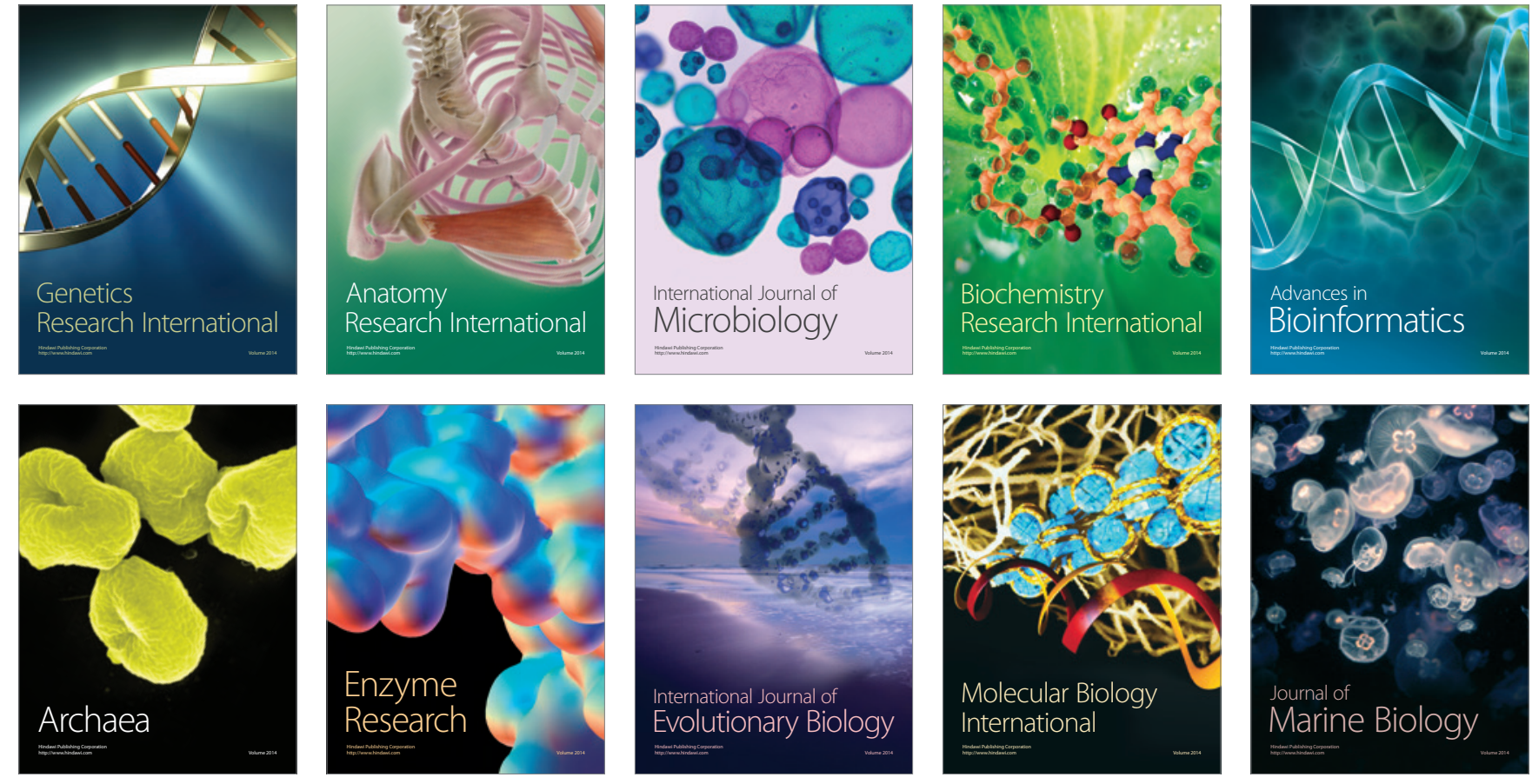